NBER WORKING PAPER SERIES

\author{
THE SEESAW PRINCIPLE IN \\ INTERNATIONAL TAX POLICY
}

\author{
Joel Slemrod \\ Carl Hansen
}

Roger Procter

Working Paper No. 4867

\author{
NATIONAL BUREAU OF ECONOMIC RESEARCH \\ 1050 Massachusetts Avenue \\ Cambridge, MA 02138 \\ September 1994
}

\begin{abstract}
Many thanks are due to Winton Bates, Chris Pinfield, John Wallace and Peter Wilson for helpful comments on various drafts of this paper. Any remaining errors are of course the responsibility of the authors. Joel Slem wed is Professor of Economics, Professor of Business Economics and Public Policy, and Director of the Office of Tax Policy Research at the University of Michigan. Carl Hansen is a Chief Analyst in the International Tax Section of the New Zealand Treasury and Roger Procter is Director of Tax Policy at the New Zealand Treasury. This paper is part of NBER's research programs in International Trade and Investment and Public Economics. Any opinions expressed are those of the authors and not those of the New Zealand Treasury or the National Bureau of Economic Research.

(C) 1994 by Joel Slemrod, Carl Hansen and Roger Procter. All rights reserved. Short sections of text, not to exceed two paragraphs, may be quoted without explicit permission provided that full credit, including (?) notice, is given to the source.
\end{abstract}


NBER Working Paper \#4867

September 1994

THE SEESAW PRINCIPLE IN
INTERNATIONAL TAX POLICY

\begin{abstract}
The standard analysis of the optimal international tax policy of a small country typically assumes that the country either imports or exports capital, but does not do both. This paper considers the situation in which a small country both exports and imports capital and can alter its tax on one or the other, but not both. In each case, a "seesaw" relationship is identified, in which the optimal tax on the income from capital exports (imports) is inversely related to the given tax rate on income from capital imports (exports). The standard results for optimal taxation of capital exports and imports are shown to be special cases of the more general seesaw principle.
\end{abstract}

Joel Slemrod

School of Business Administration

University of Michigan

Ann Arbor, MI 48109-1234

and NBER

Roger Procter

New Zealand Treasury

PO Box 3724

Wellington

NEW ZEALAND
Carl Hansen

New Zealand Treasury

PO Box 3724

Wellington

NEW ZEALAND 


\section{THE SEESAW PRINCIPLE IN INTERNATIONAL TAX POLICY}

\section{Introduction}

The normative literature on taxation of capital income flows typically divides into two streams of analysis, separately deriving the optimal tax on income from capital exports and the optimal tax on income from capital imports. Apart from the usual references to the pure residence and pure source principles of international tax, the two "arms" of international tax policy are rarely analysed as an integrated whole. The aim of this paper is to analyse the linkages that arise between the two arms of international tax policy when a country cannot fully optimise its international tax system. We focus on efficiency issues and do not consider equity or tax avoidance concerns.

The motivation for this approach arises from the constraints that policy makers face. For example, tax treaties constrain countries in how they tax capital exports. Similarly, the presence of foreign tax credits will generally make it undesirable to apply the classical capital import tax.

In the case of capital exports, the classical result in the literature shows that small capital exporting countries maximise national income when they tax net offshore income (i.e. income after foreign taxes are deducted) at the same rate as domestic income. ${ }^{1}$ This is often called the national welfare maximisation (NWM) approach to taxing capital exports. For a small capital importing economy, the classical result is that the optimal tax at the margin on capital imports is zero (in the absence of foreign tax credits provided by the exporting country). ${ }^{2}$

This note shows that each of these results change when the other tax is not set at the optimal rate. The national welfare maximising tax on capital exports $\left(\mu_{x}\right)$ depends on how residents are taxed on their domestic capital stock $\left(\mu_{d}\right)$ relative to

1 While the classical results have been known for some time, for example see Richman (1963). the first simple analytical derivation was provided by Feldstein \& Hartman (1979).

2 Both Gordon (1986) and Gersovitz (1987) provide simple analytical derivations, while MacDougall (1960) and Corden (1974) present graphical analyses of optimal taxation of capital imports. 
how capital imports are taxed $\left(\mu_{m}\right)$. Similarly, the optimal $\mu_{m}$ depends on $\left(\mu_{x}\right)$ and $\left(\mu_{d}\right)$. The relationship can be expressed in the general form: ${ }^{3}$

$$
\left(1-\mu_{m}\right)\left(1-\mu_{x}\right)=\left(1-\mu_{d}\right)
$$

We characterise the above expression as a "seesaw", as it shows that, for a given domestic tax rate $\left(\mu_{d}\right)$, higher taxes on capital exports require lower taxes on capital imports, and vice versa. A seesaw type relationship occurs regardless of whether the deduction or credit methods of double tax relief are used by the countries involved.

Intuition for the seesaw principle is straightforward, being simply an application of the standard theoretical result that the welfare losses from a tax can, in some circumstances, be offset by the imposition of another tax. In this case, part of the welfare losses accruing from a suboptimal tax on capital imports can be offset by imposing a "suboptimal" tax on capital exports, and vice versa. 4

This is most easily explained for the case of a small, capital-importing country. Such a country faces an infinitely elastic supply of foreign savings at some interest rate $r^{*}$. If the tax on capital imports is fixed, and domestic and foreign capital are perfect substitutes in domestic production, then the domestic capital stock is fixed and changes in capital exports induce corresponding changes in capital imports. In this situation, the domestic country can increase its income by expanding both exports and imports of capital, leaving the domestic capital stock unchanged, if the social return from capital exports exceeds the social cost of capital imports. 5 Similarly, when the social return from capital exports is less than the social cost of capital imports, the domestic country can increase its income by reducing equally its exports and imports. The seesaw principle simply describes the combinations of $\mu_{\mathrm{m}}, \mu_{\mathrm{d}}$ and $\mu_{\mathrm{x}}$ which ensure that domestic residents - seeking to maximise the after-tax (private) returns from their investments - exploit all opportunities for socially profitable arbitrage of exports and imports of capital. 6

Note, $\mu_{m}+\mu_{x}=\mu_{d}$ approximates the seesaw relationship described in the text.

4

Readers untamiliar with international tax may gain some insight for the seesaw result by drawing an analogy with tarift compensation arguments in the intemational trade literature. See Corden (1974) and Clements \& Sjaastad (1984).

We find it usetul to refer to the simultaneous increase in capital exports and capital imports as "social arbitrage", since the domestic economy is effectively obtaining capital from the foreign country at some interest rate and reinvesting it in the foreign country at a higher aftertax interest rate. Inconsistent tax treatment of the capital inflow with respect to the capital outflow produces such socially-profitable arbitrage opportunities for the domestic country. 
In some situations the first best option for a small open economy may involve taxing income denived from inward foreign investment. This occurs when other countries provide foreign tax credits to their capital exporters, which an importing country can only benefit from if it taxes those exporters. Interestingly, our results show that, with a fixed tax rate on capital imports, foreign tax credits received on capital imports are irrelevant for choosing optimal capital export taxes. The reverse does not hold, however. The optimal value for the capital import tax (with a fixed tax on capital exports) equals the maximum of either: (1) available foreign tax credits, or (2) the value of $\mu_{m}$ suggested by the seesaw principle. The underlying rationale for these results is given in the body of the paper.

The next section discusses related developments in the literature. The basic model for the subsequent analysis is presented in Section 3. Section 4 analyses the optimal tax on capital exports assuming taxes are fixed on capital imports. Section 5 reverses the situation, and derives the optimal tax on capital imports given that taxes on capital exports are fixed. Section 6 analyses national welfare maximisation when a country is free to choose both taxes. Conclusions and directions for further research are presented in Section 7.

\section{Related Literature}

The literature on optimal international taxation is usefully divided into two separate strands. One strand focuses on the situation where one or more of the countries is large, with results analogous to optimal taniff theory in international trade (Kemp (1962 \& 1966), Jones (1967), Feldstein \& Hartman (1979)). Where both countries are large, opportunities for strategic interaction between countries anse, and relations between capital import taxes imposed by one country and capital export taxes imposed by the other country are derived (Hamada (1966), Bond \& Samuelson (1989) and Gordon (1992)).

The second strand focuses on optimal international taxation for small open economies that either export or import capital, but not both. The classical results referred to in the introduction fall within this strand. As Bruce (1992) has recently made clear, two alternative approaches can be used to denive the classical results: either (1) one can assume that the total wealth of residents of each country is fixed, or (2) one can assume that optimal taxes are levied on both labor income and economic profits so that the Diamond and Mirrlees (1971) production efficiency results hold.

6 Note that the arbitrage behaviour in this model does not require individual firms (or people) to simultaneously export and import capital. Rather, the act of one firm exporting an extra dollar of capital induces another firm to import a dollar of capital. 
Under the first approach, if taxes are imposed on capital owned by domestic residents, regardless of location, they will fall entirely on savers and no deadweight losses are imposed on the economy. As a result, the optimal capital export and capital import taxes for a small open economy are also characterised by zero deadweight losses.

More specifically, when total wealth is fixed, an extra dollar of capital exports reduces the domestic capital stock by one dollar, so that the opportunity cost of capital exports is simply the marginal product of capital. In this situation, the optimal capital export tax for a small open economy occurs when the social return from capital exports equals the marginal product of capital (i.e., zero deadweight losses). ${ }^{7}$ This is achieved when residents are taxed on their offshore income, net of foreign taxes, at the same rate as they are taxed on their domestic income. Similarly, zero deadweight losses on capital imports occur when capital imports are taxed at a zero rate (assuming no foreign tax credits).

Subsequent developments in the literature relaxed the assumption of fixed total wealth, which alters the opportunity cost of capital exports. In Dutton (1982), ${ }^{8}$ the opportunity cost of capital exports is a combination of:

(1) a weighted average of pre- and after-tax rates of returns on domestic capital, since an extra dollar of capital exports now draws capital partly from new savings as well as domestic production; and,

(2) the extent to which the after-tax return differs from the "Golden Rule" growth rate, $n$. If the capital-labour ratio is below (above) the level necessary to sustain economic growth at rate $n$, then an extra dollar of capital exports can push the economy closer to (away from) n.9

The optimal capital export tax in Dutton's model is where the social return from capital exports equals the opportunity cost of capital exports, which implies zero

The social retum on capital exports equals the pre-tax retum less foreign taxes, whereas the private retum to capital exporters equals the pre-tax retum less all taxes.

Horst (1980) previously analysed the innlications of introducing a domestic savings elasticity. but did so trorn a world welfare perspective, whereas Dutton focuses on national welfare. Dutton (1986) extends the analyses to an overlapping generation model.

Based on Feldstein (1978), taxes on capital income alter the relative prices of present and tuture consurnption, and thereby aher the life-cycle distribution of consumption. With variable total wealth, an extra dollar of capital exports raises pre-tax and after-tax returns on domestic capital. The higher after-tax returns push the rate of tirne preference closer to (or away from) the "Golden Rule" growth path. 
deadweight losses on capital exports. ${ }^{10}$ But as Findlay (1986, p.208) points out, zero deadweight losses are not optimal when total wealth is variable. Instead, the optimal capital export tax is where marginal deadweight losses on capital exports equal marginal deadweight losses on domestic capital income tax (for a fixed revenue target). Similarly for the optimal capital-import tax. Unless savings are totally inelastic, the optimal capital export and capital import taxes are not the same as in the classical analysis. But as Bruce (1992) shows, this may require negative taxes on international capital income (i.e., a subsidy).

More specifically, in Findlay's model the government must impose distortionary taxes on residents' domestic capital income to raise revenue. This reduces saving below its optimal level but leaves investment unaffected because of the infinitely elastic supply of foreign savings to the domestic economy. Imposing some tax on capital imports becomes optimal because it raises pre-tax returns in the domestic economy, which reduces the domestic capital stock below its optimal level but increases domestic savings toward its optimal level. Thus, the optimal tax on capital imports involves trading off the welfare losses from reducing the domestic capital stock against the welfare gains from reducing the savings distortion. This countervailing aspect of capital import taxes on other tax distortions plays a critical role in the seesaw principle established in the current paper.

A completely different approach to the above literature is to assume that both labor income and economic profits are taxed optimally. Provided all capital income taxes fall entirely on saving, the capital/labor tax mix will already be optimal and so any attempt to use capital import or capital export taxes to lighten the tax burden on saving (as in Findlay) will be suboptimal. This means that the classical results for capital imports and exports are optimal even when total wealth is variable (see Gordon (1986)). ${ }^{11}$

Under Dutton's formulation, factor (1) in the previous paragraph makes the opportunity cost of capital lower than the marginal product of capital. The optimal capital export tax is therefore below the level suggested by the classical result. Factor (2), however, has the potential to raise the optimal tax rate above the classical result. Indeed, with some moderate parameters Dutton shows in a footnote that the optimal tax on capital exports would be $64 \%$ when the domestic tax rate is $33 \%$.

11 Another, and perhaps more direct, explanation is provided by Bruce (1992). A small capitalimporting country faces a perfectly elastic supply of capital imports, which means that any taxes levied on capital imports are fully shitted onto immobile factors, such as labor. The higher indirect tax burden on labor has the same effect as taxing labor directly, but in addition the capital import lax distorts imvestment levels. The latter can be avoided without imposing other costs by exempting capital imports and taxing labor directly. Taxing income from capital exports (net of foreign taxes) at the same rate as domestic income avoids similar investment distortions. 
The correct approach depends on which assumptions are realistic. For instance, if labor taxes are suboptimal and cannot be made optimal, then international taxes can be used as second-best devices to ameliorate these distortions (as suggested by Findlay). But if policy makers do not know whether labor is taxed above or below its optimal rate, then the approach followed by Gordon (1986) might be just as realistic.

The above models assume that a country cannot be both a capital exporter and capital importer. This is a significant shortcoming of the existing literature, since simultaneous exporting and importing of capital fundamentally alters the opportunity cost of capital exports. When the supply of foreign savings to the domestic economy is perfectly elastic, the opportunity cost of capital is given by the (fixed) world after-tax return on capital, and the domestic saving and production effects analysed by Dutton (1982) and Findlay (1986) become irrelevant to determining the opportunity cost of capital exports. Thus, our model differs substantially from the earlier literature. Since we want to highlight the implications of simultaneous exporting and importing of capital and compare them with the classical results, we assume that total wealth is fixed in each country.

Simultaneous exporting and importing of capital occurs if domestic and foreign capital are differentiated, such as occurs when the returns to an investor depend on specialised knowledge. But even if domestic and foreign capital were homogeneous, simultaneous importing and exporting of capital could occur if a country taxes capital exports in a manner that is not perfectly consistent with the taxes it imposes on capital imports, or if foreign countries adopt inconsistent tax policies. In this case, a country can import capital at a social cost which can be higher or lower than the social return from exporting capital. Since most countries' tax relationships are far from being perfectly consistent, this paper explores the national welfare consequences of such inconsistencies and identifies the optimal relationship between capital import taxes and capital export taxes, and vice versa.

Slemrod (1988) discusses the implications of inconsistent tax arrangements for capital market equilibrium in a world comprising two countries. That paper shows that with perfect capital mobility, equilibrium in the world capital market requires that both countries must impose the same relation between taxes on exported and domestic capital. In the absence of consistent tax policies, the potential for unlimited arbitrage profits arises. Frenkel, Razin \& Sadka (1991) make the same point but explicitly incorporate taxes on capital imports.

Slemrod (1990) analyses national weifare maximisation in a model of two countries (a Northern country and a Southern country) which impose "inconsistent" tax treatments on cross border capital flows. The model assumes that Northern residents incur monitoring costs on their investments in the South, but Southern residents do not face monitoring costs on their investments in the North. This 
structure generates non-corner solutions, with limited arbitrage gains, for national and world capital market equilibrium. The paper identifies the potential arbitrage gains or losses facing the Southern country arising from inconsistent tax settings with the Northern country, and shows that the Southern country could benefit from imposing taxes on capital exports to the Northern country.

Our paper models simultaneous importing and exporting of capital using essentially the same structure as in Slemrod (1990). Using this structure, we identify explicitly the optimal relationship between taxes on capital imports and capital exports. This leads us to the seesaw relationship that arises between the two arms of international tax policy, which is the focus of this paper.

\section{The Basic Analytlcal Model}

We assume a two-country world, where one country is calied the Southern country and the other is the Northern country. Total wealth of each country's representative citizen are assumed to be fixed, and are denoted $W_{s}$ and $W_{n}$, for the South and North, respectively. $W_{i j}$ denotes wealth owned by citizens of country $i$ and invested in country j. $K_{s}$ and $K_{n}$ denote the capital stocks located in the South and North, respectively. Thus:

$$
\begin{array}{ll}
W_{n}=W_{n n}+W_{n s} & K_{n}=W_{n n}+W_{s n} \\
W_{s}=W_{s n}+W_{s s} & K_{s}=W_{s s}+W_{n s}
\end{array}
$$

The North is assumed to be large relative to the South, so that investment by Southern residents has no impact on Northern rates of return. In contrast, Northern residents investing in the South affect the rates of return in the Southern country. Let

$\mathrm{g}\left(\mathrm{K}_{\mathrm{s}}\right)=$ Southern country production function, with $\mathrm{g}^{\prime}>0$ and $\mathrm{g}^{\prime \prime}<0$. The same production function applies regardless of whether the capital is owned by Northerners or Southerners.

$\mathbf{R}_{\mathbf{s}} \quad=$ pre-tax rate of return earned on capital located in the South

$=\mathbf{g}^{\prime}$.

$R_{n}=$ (constant) pre-tax rate of return earned on capital located in the North.

Each country can tax its residents on their domestic and offshore income, at separate rates if desired. Furthermore, each country can tax non-residents' income earned within its borders. Thus, the North may impose three separate taxes; denoted 
$\tau_{\mathrm{nn}}=$ tax rate on Northerners earning Northern income

$\tau_{\mathrm{ns}}=$ tax rate on Northerners eaming Southern income

$\tau_{\mathrm{sn}}=$ tax rate on Southerners earning Northern income

and the South may impose three separate taxes; denoted

$\mu_{\mathrm{ss}}=$ tax rate on Southerners earning Southern income

$\mu_{\mathrm{sn}}=$ tax rate on Southerners earning Northern income

$\mu_{\mathrm{ns}}=$ tax rate on Northerners earning Southern income

The above set of taxes potentially result in "double taxation" of cross border capital income. Countries use a number of different approaches to reduce double taxation. Whatever method is used, we denote the resulting effective tax rate imposed by both countries as:

$v_{n s}=$ effective tax rate on Northerners earning Southern income; and,

$v_{\mathrm{sn}}=$ effective tax rate on Southerners earning Northern income.

For simplicity, we assume all taxes are levied on an accrual basis. Thus, for example, if the South operates a worldwide tax system with a limited foreign tax credit then $v_{\mathrm{sn}}=\max \left(\tau_{\mathrm{sn}}, \mu_{\mathrm{sn}}\right)$. If the South operates the territorial or exemption system, $\mu_{s_{n}}=0$ and $v_{s_{n}}=\tau_{s n}$ if it operates a deduction system

$\left(1-v_{s n}\right)=\left(1-\tau_{s n}\right)\left(1-\mu_{s n}\right)$. Similar definitions apply in the case of the North.

It will be useful for discussion of the results to denote as $\eta_{s n}$ the net tax rate that the South imposes on $W_{s n}$ over and above what the North imposes. This is given by $\left(1-\eta_{s n}\right)=\left(1-v_{s n}\right) /\left(1-\tau_{s n}\right)$.

\section{Investor Equilibrium}

In a world with perfect capital mobility, Southern residents would in equilibrium earn the same after-tax return on both Southern and Northern investments:

$$
\left(1-\mu_{s s}\right) g^{\prime}=\left(1-v_{s n}\right) R_{n} .
$$

Similarly, equilibrium for the Northern investor requires:

$$
\left(1-\tau_{n n}\right) R_{n}=\left(1-v_{n s}\right) g^{\prime}
$$


It is readily apparent that the conditions in (1a) and (1b) lead to an interior world capital market equilibrium if and only if tax rates fulfill the following constraint

$$
\left(1-v_{s n}\right)\left(1-v_{n s}\right)-\left(1-\tau_{n n}\right)\left(1-\mu_{s s}\right) \equiv \theta=0
$$

As Slemrod (1988) and Frenkel, Razin \& Sadka (1991) discuss, if condition (2) does not hold, either (1a), (1b) or both, will not hold, presenting the possibility of infinite arbitrage profits by holding a short position in the low-yielding asset and a long position in the higher-yielding asset. In Slemrod (1988), equilibrium is obtained by ruling out short positions.

In reality, arbitrage opportunities are limited by factors like information costs, portfolio risk and limited tax deductibility of interest expenses. Incorporating these factors means that Northern and Southern capital are imperfect substitutes, and therefore we essentially have a "two-good" portfolio optimisation problem. 12 Adopting this approach involves extra complexity without providing greater insight to our results. As our primary objective is to draw out the key tax relationships and compare them with the classical results under the same conditions, we continue to treat all capital as one good and posit that there are increasing marginal costs to Southern investment in the North. For ease of exposition, we refer to these costs as monitoring costs, but they are more appropriately thought of as reflecting the degree of imperfect substitutability in the model. This feature of the model provides an interior solution to the gross capital flows across borders, and allows for limited arbitrage opportunities.

This assumption leads us to change (1a) to:

$$
\left(1-\mu_{s s}\right) g^{\prime}=\left(1-v_{s n}\right)\left(R_{n}-c^{\prime}\left\{W_{s n}\right\}\right)
$$

where $c^{\prime}\left(W_{s n}\right)$ represents the marginal monitoring cost of the cross-border investment by Southerners, ${ }^{13}$ We assume that $c^{\prime}(0)=0$ and that $c^{\prime \prime}>0$ for $W_{s n}>0$. In the following analysis, we focus on the case in which net cross-border capital flows are always positive (ie. $W_{s n}>0$ and $W_{n s}>0$ ), which occurs when $\theta>0.14$

12 A two-good" model of capital flows would be analogous to a two-good intemational trade model in which a country uses export subsidies to oftset the adverse effects on its exports of tarifts it imposes on imports (i.e., "tariff compensation"). See Corden (1974) for an example of this literature.

13 Note that this treatment assumes that $c^{\prime}$ is tax deductible, which will be true for some costs including monitoring costs - but not for other factors such as risk premia. We adopt this approach because it means the classic results can be derived from the model, and therefore the implications of the seesaw results have a straightforward interpretation. 
In this setting, inconsistent tax arrangements between the North and South drive cross border capital flows to the point where the monitoring cost on the marginal investment $\left(c^{\prime}\right)$ rises sufficiently to eliminate further arbitrage activity.

To see this, note that (1c) and (1b) can be written as

$$
\begin{aligned}
& g^{\prime}=\frac{\left(1-v_{s n}\right)\left(R_{n}-c^{\prime}\right)}{\left(1-\mu_{s s}\right)}, \\
& g^{\prime}=\frac{\left(1-\tau_{n n}\right) R_{n}}{\left(1-v_{n s}\right)} .
\end{aligned}
$$

Since (3a) and (3b) both hold in equilibrium, we have:

$$
c^{\prime}=\frac{\theta R_{n}}{\left(1-v_{n s}\right)\left(1-v_{s n}\right)} .
$$

where $\theta$ is given in (2). Thus, $c^{\prime}$ is zero when condition (2) holds. Equation (4) shows that consistent tax policies between the North and South (ie. $\theta=0$ ) eliminate all costly capital flows, so that $\mathrm{W}_{\mathrm{sn}}=0$.

It is instructive to compare this equilibrium with that obtained in the standard model under consistent tax settings. In that case the Southern resident is indifferent between domestic and foreign investments, so that $W_{s n}$ is indeterminate rather than zero. Net capital exports $\left(W_{s}-K_{s}\right)$ are determinate, but not gross capital exports or imports.

\section{MaxImlsing Southern Welfare from Taxing Capital Exports}

As discussed in the introduction, a classical result in the international tax literature is that individual countries maximise national income from capital exports when they tax net offshore income (i.e. income after foreign taxes are deducted) at the same rate as domestic income. This is known as the deduction approach to relieving double taxation, and it would be represented in our notation by $\left(1-v_{s n}\right)=\left(1-\mu_{s n}\right)\left(1-\tau_{s n}\right)$, and $\mu_{s n}=\mu_{s s}$.

$14 \theta>0$ means that cross border investments, $W_{s n}$ and $W_{n s}$, are effectively taxed more lightly than domestic investments, $W_{s s}$ and $W_{n n}$. Less restrictive tax arrangements (e.g., $\left.\theta<0\right)$ could also be modelled if either (a) $W_{s n}$ and $W_{n s}$ could take negative values, or (b) Southerners incurred monitoring costs and investment risk on domestic as well as offshore investment, so that $c^{\prime}$ reflected net costs and could take negative values. The underlying logic of the results, however, does not depend on these assumptions. 
The classical result obtains because the opportunity cost of capital exports for a country shut-off from capital imports is the marginal product of capital, $\mathrm{g}^{\prime}$. At an optimum, the national return to foreign investment, $\left(1-\tau_{s n}\right) R_{n}$, should equal this opportunity cost. The Southern investor will ensure that $\left(1-\mu_{\mathrm{ss}}\right) g^{\circ}=\left(1-v_{\mathrm{sn}}\right) R_{\mathrm{n}}$. These two conditions generate the optimal amount of foreign investment as long as $\left(1-\mu_{s s}\right)=\left(1-v_{s n}\right) /\left(1-\tau_{s n}\right)$, which it does under a full taxation with deduction approach.

In an economy open to capital imports, the opportunity cost of capital is a function of the world cost of capital. In the extreme case where an extra dollar of capital exports induces an additional dollar of capital imports, the opportunity cost of capital equals the pre-tax return paid to imported capital less any taxes received by the capital importing country (in this case, the South).

This situation can be analysed by defining national income in the South $\left(Y_{s}\right)$ as:

where $\quad C\left(W_{s n}\right)=\frac{S_{s n} c^{\prime}(z) d z}{W_{s n}}$.

Equation (5) reflects the fact that $g^{\prime} W_{n s}$ of the income from local production accrues to Northern investors; however, the South collects tax revenue on that income so the net payment to Northerners equals $\left(1-\mu_{n s}\right) g^{\prime} W_{n s}$ Similarly, net income accruing to Southern residents investing in the North is $\left(1-\tau_{s n}\right)\left(R_{n}-C\right) W_{s n}$. where $\mathrm{C}$ is the average monitoring cost on these investments.

The problem at hand is for the Southern country to set taxes on its residents investing in the North $\left(\mu_{\mathrm{sn}}\right)$ at the level that maximises national income, assuming all other taxes (including its own fiscal instruments $\mu_{s s}$ and $\mu_{n s}$ ) are fixed. ${ }^{15}$ in particular, $\mu_{n s}$ is constant and therefore $v_{n s}$ is constant. This means that $g$ ' is constant since from (3b) $g^{\prime}=\left(1-\tau_{n n}\right) R_{n} /\left(1-v_{n s}\right)$. Totally differentiating (5) and rearranging yields

$$
d Y_{s}=\frac{g^{\prime}\left(1-\mu_{n s}\right)\left(1-\tau_{n n}\right) R_{n}}{\left(1-v_{n s}\right)} d K_{s}+I\left(1-\tau_{s n}\right)\left(R_{n}-c^{\prime}\right)-\frac{\left(1-\mu_{n s}\right)\left(1-\tau_{n n}\right) R_{n}}{\left(1-V_{n s}\right)} d W_{s n} .
$$

15 As is standard in this literature, no revenue constraint is imposed. The implicit assumption is that the South has at its disposal other fiscal instruments which cause no excess burden, in particular taxes on immobile factors, to meet its revenue needs. 
Since a change in $\mu_{\mathrm{sn}}$ has no effect on the domestic capital stock (that is, $\mathrm{dK}_{3} / \mathrm{d} \mu_{\mathrm{sn}}=0$ ), the first term is irrelevant to this optimisation problem; it will become relevant in section 5 when we discuss the optimal setting of $\mu_{n s}$. We focus on the second term. The first component is the marginal social return the South receives when its residents invest in the North, and the second component is the social cost to the South of Northerners investing in the South. Since the South's capital stock $\left(K_{s}\right)$ is constant, increasing $W_{s n}$ by $\$ 1$ increases $W_{n s}$ by $\$ 1$. The South must forgo $\left(1-\mu_{n s}\right)\left(1-\tau_{n n}\right) R_{n} /\left(1-v_{n s}\right)$ to attract a dollar of $W_{n s}$. Thus, an increase in $W_{s n}$ increases $Y_{s}$, provided the social return from increasing $W_{s n}$ exceeds the social cost of increasing $W_{n s}$. This net return is positive at $W_{s n}=0$ (and thus $c^{\prime}=0$ ) when $\theta>0$, and measures the arbitrage gain from obtaining capital from the North and simultaneously investing in the North. This arbitrage gain is limited because $C^{\prime}$ increases as $\mathrm{W}_{\mathbf{s n}}$ increases. The South's national income is maximised when $\mathrm{W}_{\mathbf{s n}}$ is increased to the point that $c^{\prime}\left(W_{s n}\right)$ makes the marginal net social gain zero.

We can show this result formally by totally differentiating (1b) and (1c) while holding all taxes constant, except $\mu_{\mathrm{sn}}$, obtaining

$$
\begin{aligned}
& \left(1-v_{n s}\right) g^{n} d K_{s}=0 \Rightarrow d K_{s}=0 \text {, and } \\
& d W_{s n}=\frac{-\left(R_{n}-c^{\prime}\right) d v_{s n}}{\left(1-v_{s n}\right) c^{\prime \prime}} \text {, since } d K_{s}=0 .
\end{aligned}
$$

Substituting (7a) and (7b) into (6) gives the first-order condition for an optimum (i.e., where $\partial \mathrm{Y}_{\mathrm{s}} / \partial v_{\mathrm{sn}}=0$ ).

(8) $\frac{\left(1-\tau_{s n}\right)\left(R_{n}-c^{\prime}\right)}{\left(1-\mu_{n s}\right)}=\frac{\left(1-\tau_{n n}\right) R_{n}}{\left(1-v_{n s}\right)}$.

After substituting from (3a) and (3b), and remembering that $\left(1-\eta_{s n}\right) \equiv$ $\left(1-v_{s n}\right) /\left(1-\tau_{s n}\right)$, we can find the tax rates for which the equilibrium outcome is consistent with this expression, which is

(9) $\quad\left(1-\eta_{\mathrm{sn}}\right)=\frac{\left(1-\mu_{\mathrm{ss}}\right)}{\left(1-\mu_{\mathrm{ns}}\right)}$.

Equation (9) is what we call the general seesaw result for taxing capital exports. Given the assumption that the South can not alter $\mu_{\mathrm{ss}}$ or $\mu_{\mathrm{ns}}$, the higher the value of $\mu_{n s}$ that the South imposes, the lower the net tax rate $\left(\eta_{\mathrm{sn}}\right)$ the South needs to impose on capital exports to maximise national income, and vice versa. 
Perhaps the most surprising aspect of equation (9) is that it includes $\mu_{n s}$ and not $v_{n s}$. This means that when $\mu_{n s}$ is fixed, foreign tax credits provided by the North have no effect on the South's optimal tax rate on capital exports. ${ }^{16}$ The reason is that such credits are in fact a subsidy on Northern capital supplied to the South $\left(\mathrm{W}_{\mathrm{ns}}\right)$, which does not alter the South's tax wedge on capital imports (i.e., both the private and social cost of capital imports decline by the same amount). The reduction in social cost increases the optimal level of capital exports and imports, and the reduction in private cost automatically induces private agents to achieve the new optimum without the South altering its capital export taxes.

There are two other general points to note about equation (9). Even though $\eta_{s n}$ can be a function of $\tau_{s n}$, its optimal value does not depend on $\tau_{\mathrm{sn}}$. This means the optimal capital export tax for the South does not depend on Northern taxes. Second, if $\mu_{n s}>\mu_{s s}$, then (9) requires that $\eta_{s n}$ be negative. If $\eta_{s n}$ is restricted to positive values, then the greatest welfare is obtained when $\eta_{\mathrm{sn}}=0$.

If the South utilises a deduction approach to double tax relief, then $\left(1-v_{s n}\right)=\left(1-\mu_{s n}\right)\left(1-\tau_{s n}\right)$, so that $\left(1-\eta_{s n}\right)=\left(1-\mu_{s n}\right)$. It follows from (9) that the classical result for maximising welfare from capital exports (the deduction system with $\mu_{s n}=\mu_{s s}$ ) is optimal only when $\mu_{n s}=0$. As long as there is positive tax on capital imports $\left(\mu_{n s}>0\right)$, then the optimal taxation of capital exports falls short of full taxation with deductibility.

If instead the South utilises the foreign tax credit method of relieving double taxation, (9) becomes:

$$
\frac{\left(1-\mu_{s n}\right)}{\left(1-\lambda_{s}\right)}=\frac{\left(1-\mu_{s s}\right)}{\left(1-\mu_{n s}\right)}
$$

where $\lambda_{s}$ denotes foreign tax credits the South provides to its residents investing in the North. ${ }^{17,18}$ Under a limited foreign tax credit system $\lambda_{s}=\min \left(\mu_{s n}, \tau_{s n}\right)$, whereas $\lambda_{s}=\tau_{s n}$ under a pure foreign tax credit system. Equation (10) shows that the optimal value for $\mu_{s n}$ is increased directly by the amount of foreign tax credits, so as to leave the net tax rate at the same level as under the deduction approach.

16 This conclusion does not hold in the next section, where we set $\mu_{n s}$ to maximise Southem income.

17 As with all taxes, all foreign tax credits are assumed to be provided on an accrual basis.

18 We derive (10) from the fact that the net tax rate, $\left(1-v_{\mathrm{sn}}\right) /\left(1-\tau_{\mathrm{sn}}\right)$, is identical to $\left(1-\mu_{s n}\right) /\left(1-\lambda_{s}\right)$, for both accrual methods of foreign tax selief. 
The two most commonly used methods of double tax relief around the world are the exemption system and the limited foreign tax credit system. The exemption approach sets $\eta_{s n}=0$, which satisfies the seesaw condition only when $\mu_{n s}=\mu_{s s}$. A limited foreign tax credit system is consistent with the seesaw condition only when $\mu_{n s} \leq \mu_{s s}$. If $\mu_{n s}=\mu_{s s}$, it is desirable to levy no net tax on exports, which can be achieved by ensuring that $\mu_{5 n} \leq \tau_{s n}$ and granting a limited credit for foreign taxes. If $\mu_{\mathrm{ss}}<\mu_{\mathrm{ss}}$, it is desirable to impose some positive net tax on exports. This can be accomplished by setting $\mu_{\mathrm{sn}}$ appropriately larger than $\tau_{\mathrm{sn}}$ and offering a credit for $\tau_{\text {sn }}$.

\section{Maximising Southern Welfare from Taxing Capital Imports}

The above analysis assumed that the South could set only $\mu_{\mathrm{sn}}$ in its effort to maximise national income. This section analyses the reverse situation, where the South can only alter taxes it imposes on Northerners investing in the South $\left(\mu_{n s}\right)$, while $\mu_{s n}$ and $\mu_{s s}$ are assumed fixed.

National income in the South $\left(\mathrm{Y}_{3}\right)$ is again given by equation (5). In contrast to the previous section, equations (3a) and (3b) indicate that variations in $\mu_{\mathrm{ns}}$ may change $K_{B}$ and therefore $g^{\prime}$, since $v_{n s}$ is a function of $\mu_{n s}$. The value of $\mu_{n s}$ which maximises Southern income is determined by differentiating (5), holding all tax variables constant except $\mu_{n s}$. We get

$$
\begin{aligned}
d Y_{s} & =\mu_{n s} g^{\prime} d K_{s}+g^{\prime} W_{n s} d \mu_{n s} \\
& +\left[\left(1-\tau_{n s}\right)\left(R_{n}-c^{\prime}\right)+\frac{\left(1-\mu_{n s}\right)\left(1-\nu_{s n}\right) W_{n s} c^{\prime \prime}}{\left(1-\mu_{s s}\right)}-\frac{\left.\left(1-\mu_{n s}\right)\left(1-\tau_{n n}\right) R_{n}\right]}{\left(1-\nu_{n s}\right)} d W_{s n}\right.
\end{aligned}
$$

Similarly, totally differentiating (1c) and (1b) while holding all taxes constant except $\mu_{n s}$ (and therefore $v_{n s}$ ) gives

$$
\begin{aligned}
& \mathrm{dW}_{s n}=\frac{-\left(1-\mu_{s s}\right) \mathrm{g}^{\prime \prime}}{\left(1-v_{s n}\right) \mathrm{c}^{\prime \prime}} \mathrm{dK}_{\mathrm{s} .} \quad \text { For later use, let } \delta=\frac{\mathrm{c}^{\prime \prime}\left(1-\nu_{\mathrm{sn}}\right)}{\mathrm{g}^{\prime \prime}\left(1-\mu_{s s}\right)}=\frac{-\mathrm{d} \mathrm{K}_{\mathrm{s}}}{\mathrm{dW_{sn }}} \\
& \mathrm{dK}_{\mathrm{s}}=\frac{\mathrm{g}^{\prime} \mathrm{d} v_{\mathrm{ns}}}{\left(1-v_{\mathrm{n}}\right) \mathrm{g}^{\prime \prime}}
\end{aligned}
$$

Substituting for $\mathrm{dK}_{\mathrm{s}}$ and $\mathrm{dW}_{\mathrm{sn}}$ into (11) gives: 


$$
d Y_{s}=\frac{\mu_{n s} g^{\prime} g^{\prime} d v_{n s}}{g^{\prime \prime}\left(1-v_{n s}\right)}+g^{\prime} W_{n s} d \mu_{n s}
$$

$-\left[\left(1-\tau_{s n}\right)\left(R_{n}-c^{\prime}\right)+\frac{\left(1-\mu_{n s}\right)\left(1-v_{s n}\right) W_{n s} c^{\prime \prime}}{\left(1-\mu_{s s}\right)}-\left(1-\mu_{n s}\right) g^{\prime}\right] \frac{\left(1-\mu_{s s}\right) g^{\prime} d v_{n s}}{\left(1-v_{s n}\right)\left(1-v_{n s}\right) c^{\prime \prime}}$

In this case, the optimal tax policy depends on the method used by the North to eliminate double taxation. If the North operates the deduction approach to double tax relief, then $\left(1-v_{n s}\right)=\left(1-\mu_{n s}\right)\left(1-\tau_{n s}\right)$ and $d v_{n s}=\left(1-\tau_{n s}\right) d \mu_{n s}$. The first-order conditions reduce to:

$$
\begin{aligned}
& \mu_{n s}=\frac{\left(\mu_{s s}-\eta_{s n}\right)}{\left(1-\eta_{s n}\right)(1+\delta)}, \text { or } \\
& 1-\mu_{n s}=\frac{\left(1-\mu_{s s}\right)}{\left(1-\eta_{s n}\right)(1+\delta)}+\frac{\delta}{(1+\delta)}
\end{aligned}
$$

where $\delta$ is given by (12a). Note that the optimal value for $\mu_{n s}$ depends on the net tax rate the South imposes on Southerners investing in the North, $\eta_{s n}$. Thus, if $\mu_{s n}$ is fixed and the South gives foreign tax credits to partially offset $\mu_{s n}$, then the optimal tax on capital imports is higher than if no foreign tax credits were given.

Equation (14) shows that the classical result for taxing rapital imports in the absence of foreign tax credits, $\mu_{n s}=0$, is optimal only when $\eta_{s n}=\mu_{s s}$. Also, comparing equation (14') with (9), it is apparent that the seesaw relationship is not symmetrical for the South's two international taxes $\left(\mu_{\mathrm{sn}}\right.$ and $\left.\mu_{n s}\right)$. Taxes on capital imports affect capital imports, capital exports and the domestic capital stock (because raising $\mu_{n s}$ increases domestic interest rates), whereas capital export taxes only affect capital imports and exports in this model. Thus, the optimal setting for $\mu_{n s}$ involves trading off forgone arbitrage gains from capital exports against welfare losses from an inefficient domestic capital stock. This tradeoff is given by $\delta$ in (14) and (14'). ${ }^{19}$ If $\delta=0$ then increasing $\mu_{n s}$ has no effect on the domestic capital stock and so (14') gives a seesaw result similar to (9).20 The larger is $\delta$, the larger is the (inefficient) reduction in the domestic capital stock per dollar of arbitrage, and the lower the optimal value of $\mu_{n s}$.

The above analysis was based on the assumption that the North applies the deduction approach to Northerners investing in the South. Now consider the case

Findlay (1986) identifies a similar tradeotf.

From (12a), $\delta=0$ implies either $c^{\prime \prime}=0$ or $g^{\prime \prime}$ is infinite (assuming tax rates less than $100 \%$ ). 
in which the North uses a limited foreign tax credit system to alleviate double taxation.

First, recall that under the Northern foreign tax credit system, $v_{n s}=\max \left(\tau_{n s}, \mu_{n s}\right)$. Thus, if $\mu_{n s} \leq \tau_{n s}$ then $v_{n s}=\tau_{n s}$ and $\partial v_{n s} / \partial \mu_{n s}=0$. Increasing $\mu_{n s}$ has no effect on $K_{s}$ and therefore does not alter the private attractiveness of domestic investment $\left(W_{s s}\right)$ relative to capital exports $\left(W_{s n}\right)$. As inspection of equation (5) makes clear, increasing $\mu_{n s}$ merely reduces the social cost of capital imports by the amount of the additional tax revenue collected $\left(\mathrm{g}^{\prime} \mathrm{W}_{n s} \mathrm{~d} \mu_{\mathrm{ns}}\right)$ and has no effect on any other real variable. Therefore, maximising Southern income requires $\mu_{n s} \geq \tau_{n s}$.

If $\mu *_{n s}>\tau_{n s}$, where $\mu *_{n s}$ is the value of $\mu_{n s}$ that satisfies (14), then $\mu *_{n s}$ is optimal. This reflects the fact that increases in $\mu_{n s}$ beyond $\tau_{n s}$ affect real variables in the same way as it does if the North uses a deduction system, and therefore maximising Southern income involves the same tradeoffs encountered under the deduction system,

In summary, the South should always ensure that at a minimum $\mu_{n s}=\tau_{n s}$ in order to soak up foreign tax credits provided by the North without raising the domestic cost of capital. This is optimal even if the seesaw result in (14) suggests $\mu_{n s}<\tau_{n s}$. The seesaw result in (14) should be adhered to provided it suggests setting $\mu_{n s}>\tau_{n s}$.

\section{Maximising Total Southern Welfare}

When both $\mu_{n s}$ and $\mu_{s n}$ can be chosen optimally, this model generates the classical results: set $\mu_{n s}$ equal to zero and set $\mu_{s n}$ equal to $\mu_{s s}$ allowing a deduction for foreign taxes.

To see this, remember that the first order conditions for $\mu_{\mathrm{ns}}$ and $\mu_{\mathrm{sn}}$ are

$$
\left(1-\mu_{\mathrm{ns}}\right)=\frac{\left(1-\mu_{\mathrm{ss}}\right)}{\left(1-\eta_{\mathrm{sn}}\right)(1+\delta)}+\frac{\delta}{(1+\delta)}, \text { where } \delta=\frac{\left(1-v_{\mathrm{sn}}\right) c^{\prime \prime}}{\left(1-\mu_{\mathrm{ss}}\right) \mathrm{g}}
$$

and,

$$
\left(1-\mu_{n s}\right)=\frac{\left(1-\mu_{s s}\right)}{\left(1-\eta_{s n}\right)}
$$


As long as $\delta$ is positive, the first-order conditions represented by equations ( 9 ) and (14) are both satisfied only when $\mu_{n s}=0$. If $\mu_{n s}=0$, then $\eta_{s n}=\mu_{s s}$ from equation (9). If the South uses the deduction approach to double tax relief, then $\mu_{\mathrm{sn}}=\eta_{\mathrm{sn}}=\mu_{\mathrm{ss}}$ and we have the classical NWM result for capital exports. In other words, for a given positive value of $\mu_{s s}$, levying $\mu_{s n}$ is a more efficient means of satisfying the seesaw principle than levying $\mu_{n s}$, because using $\mu_{n s}$ involves avoidable welfare losses from distorting the domestic capital stock, whereas $\mu_{\mathrm{sn}}$ only affects capital exports.

If the North provides forelgn tax credits to the South, the optimal outcome is to set $\mu_{n s}=\tau_{n s}$ in order to soak up foreign tax credits, and set $\eta_{s n}$ at the level that satisfies the seesaw result of (9).

\section{Conclusions and Issues for Further Research}

The paper shows that the classical results for taxing capital exports and imports are optimal only if both taxes can be set at their classical level. Many countries are restricted, however, in how they tax capital exports and imports, particularly in regard to double tax agreements, but also because of economic considerations (such as foreign tax credits on capital imports) or because of the domestic political environment.

When a country cannot impose the classical tax rates, a seesaw type relationship exists, where the optimal tax on capital exports (imports) is inversely related to the fixed tax rate on capital imports (exports). The seesaw principle describes combinations of international and domestic taxes that achieve a second-best optimum for these situations. Perhaps the most surprising result is that, with a fixed tax rate on capital imports, the level of crediting of capital imports has no affect on the optimal level of capital export taxes. In all other cases, however, credits on exports and imports directly affect optimal tax rates.

If international tax policy employs the seesaw principle, domestic investors acting in their own profit-maximising interests will choose the socially optimal level of capital exports and capital imports, given the constraints on feasible tax arrangements. A country which does not adhere to the basic seesaw principle causes investors, acting individually, to produce a collective outcome for the country that is similar to a bank borrowing money at a higher interest rate than the rate it charges on its loans. The country essentially gives away national income since the social cost of capital imports exceeds the social return from capital exports. This can only be justified if capital export taxes are fixed. In this case, the extent to which capital import taxes can be used to reduce such losses is limited by the trade-off with distortions to the domestic capital stock. 
Applying the results to a multi-country framework is straightforward provided capital imports are taxed uniformly. The object is to levy the same net tax on all capital exports, which would be achieved with the deduction approach. In contrast, commonly-used crediting methods would be suboptimal, because they result in uneven net tax burdens on exports to different countries.

The results regarding capital exports alter the standard view (expressed, for example, in Slemrod (1994)), that while full taxation with deductibility is optimal from a national perspective, from a global perspective it leads to inefficient double taxation of foreign investment. From the perspective of this paper, for a country which is constrained to tax capital imports, full taxation is no longer nationally optimal.

There are a number of directions in which the seesaw analysis could be extended. For instance, a domestic savings elasticity could be introduced into the small open economy model. While the basic seesaw result in section 4 would not be affected, the asymmetry in the seesaw result of section 5 (represented by $\delta$ ) would be mitigated by the effects of the savings elasticity. Dropping the small country assumption is another obvious area for further analysis. This is likely to produce a weaker seesaw relationship in section 4, as changes in capital export taxes would produce "terms of trade" type effects on capital imports. We also speculate that it would reduce the magnitude of $\delta$ in section 5 . More fundamental extensions could be made building a "two-good" general equilibrium model to relax the assumption that domestic and foreign capital are perfect substitutes in domestic production. This would drive the results back towards that produced by the classical analysis. Further analysis to confirm these predictions will hopefully be the subject of future research. 


\section{References}

Bond, E. and L. Samuelson (1989) "Strategic Behaviour and the Rules for International Taxation of Capital", The Economic Journal, 99, pp.1099-1111.

Bruce, N. (1992) "A Note on the Taxation of International Capital Income Flows," The Economic Record, 68(202), pp.217-221.

Clements, K. \& L. Sjaastad (1984) "How Protection Taxes Exporters," Ihames Essay No.39, London:Trade Policy Research Centre.

Corden, W. (1974) Trade Pollcy and Economic Welfare, Oxford: Clarendon Press.

Diamond, P. \& J. Mirtees (1971) "Optimal Taxation and Public Production, I: Production Efficiency and II: Tax Rules", American Econemic Review, 61, pp.8-27, 261-278.

Dutton, J. (1982) "The Optimal Taxation of International Investment Income: A Comment," Quarterly Journal of Economics, 97, pp. 373-80.

Dutton, J. (1986) "Optimal Taxes on Foreign Investment in an Overlapping Generation Model," Public Finance Quarterty, 14(3), pp.289-311.

Feldstein, M. (1978) "The Welfare Costs of Capital Income Taxation," Journal of Political Economy, 86, pp. S29-S51.

Feldstein, M. and D. Hartman (1979) "The Optimal Taxation of Foreign Source Investment Income", Quarterly Journal of Economics, 93, pp.613-630.

Findlay, C. (1986) "Optimal Taxation of International Income Flows", The Economic Record, 62(177), pp.208-214.

Frenkel, J., Razin, A. and E. Sadka (1991) International Taxation in an Integrated World, Mass: The MIT Press.

Gersovitz, M. (1987) "The Effect of Domestic Taxes on Foreign Private Investment," in Newbery, D. and N. Stern, eds., The Theory of Taxation for Developing Countries, New York : Oxford University Press.

Gordon, R. (1986) "Taxation of Investment and Savings in a World Economy," American Economic Review, 76(5), pp.1086-1102. 
Gordon, R. (1992) "Can Capital Income Taxes Survive in Open Economies ?". Ihe Journal of Finance, XLVII(3), pp.1159-80.

Hamada, K. (1966) "Strategic Aspects of Taxation on Foreign Investment Income," Quarterly Journal of Economics, 80(3), pp. 361-75.

Harberger, A. (1976) "On Measuring the Social Opportunity Cost of Public Funds," in Harberger, Project Evaluatlon, Collected Papers (Chicago: University of Chicago Press, 1972, reprinted 1976), pp.94-122.

Hartman, David G. (1985) "On the Optimal Taxation of Capital Income in an Open Economy," National Bureau of Economic Research Working Paper No. 1550, Cambridge, Mass.

Horst, T. (1980) "The Optimal Taxation of International Investment Income," Quarterly Journal of Economics, 95, pp. 793-798.

Jones, R. (1967) "International Capital Movements and the Theory of Tariffs and Trade", Quarterly Journal of Economics, 81, pp.1-38.

Kemp, M. (1962) "Foreign Investment and the National Advantage", Economic Becord, 38, pp.56-62.

Kemp, M. (1966) "The Gain from International Trade and Investment: A NeoHeckscher-Ohlin Approach", American Economic Review, LVI, pp.788-809.

MacDougall, G. (1960) "The Benefits and Costs of Private Investment from Abroad: A Theoretical Approach", Economic Record, 36, pp. 13-35.

Richman, P. (1963) Taxation of Foreign Investment Income: An Economic Analysis", Baltimore: The John Hopkins Press.

Slemrod, J. (1988) "Effect of Taxation with International Capital Mobility", in Aaron, $H$., Galper, $H$. and J. Pechman, eds., Uneasy Compromise: Problems of a Hybrld Income-Consumption Tax, Washington DC: The Brookings Institution, pp.115 - 147.

Slemrod, J. (1990) "A North-South Model of Taxation and Capital Flows", National Bureau of Economic Research Working Paper No. 3238, Cambridge, Mass.

Slemrod, J. (1994) "Free Trade Taxation and Protectionist Taxation," International Tax Policy Forum Research Paper, University of Michigan. 